\title{
POLEMIKA
}

\section{Povinně cizojazyčné habilitace: mezi absurditou a ,světovostí“"?}

\author{
Awarding a Degree of Senior Lecturer Compulsorily Based \\ on a Thesis Written in Foreign Language: Between Absurdity \\ and "World-class" Fancy?
}

\author{
Josef Bejček*
}

\section{Namísto úvodu (praeter festum):}

Vedení naší univerzity se rozhodlo zavést povinné habilitace $\mathrm{v}$ cizím jazyce. Před projednáním návrhu Řádu habilitačního řízení a ř́zení ke jmenování profesorem na MU v akademickém senátu MU dne 24. dubna 2017 jsem jakožto senátor AS MU zpracoval soubor argumentů a postřehů $\mathrm{k}$ nejkontroverznějšímu ustanovení návrhu, ${ }^{1}$ které jsem zaslal panu rektorovi i všem členům AS MU. Tento dokument je př́lohou zápisu z onoho jednání. ${ }^{2}$

Považuji za užitečné seznámit s nimi touto formou i fakultní a širší odbornou veřejnost a přispět alespoň $\mathrm{k}$,náhradní“ diskusi o tomto závažném zásahu do akademického života fakulty i do podmínek rozvoje právní vědy, pokud nám již možnost věc rádně projednat na fakultách před hlasováním AS MU byla upřena. ${ }^{3}$

$\mathrm{V}$ přesvědčení o užitečnosti další diskuse a o nutnosti korigovat „habilitační zákaz rodného i úředního jazyka" mě posílily četné kladné neformální ohlasy na sepsané argumenty, ale zejména diskuse na Vědecké radě Právnické fakulty MU dne 6. června 2017, na níž se špičkoví zástupci právnické akademické obce i vrcholní představitelé naší justice bez výjimky postavili proti onomu ,jazykovému cenzu“ i proti nepríjatelnému obejití vědeckých rad fakult při prípravě tak významného zásahu do jejich kompetencí.

* Prof. JUDr. Josef Bejček, CSc., Katedra obchodního práva, Právnická fakulta, Masarykova univerzita, Brno / Department of Commercial Law, Faculty of Law, Masaryk University, Brno, Czech Republic / E-mail: Josef.Bejcek@law.muni.cz

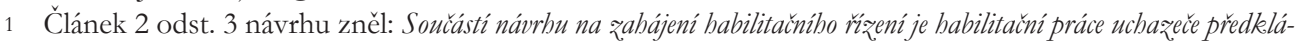

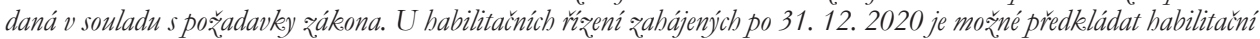

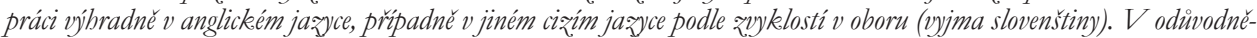

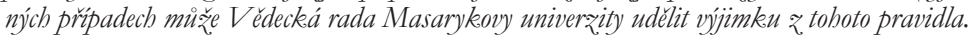

2 Srov. https://is.muni.cz/do/rect/AS/zapisy/69365452/

3 Šlo pouze o pracovní poznámky bez nároku na úplnost. Ponechávám je v autentické piơodní podobě včetně původního č́slování. Text je tedy jistým „dokumentem doby“ a později se přirozeně mohly některé názory, stanoviska a argumenty pozměnit, korigovat či rozšírít.

Č́slování nemělo vzbudit dojem exaktnosti a komplexnosti, ale mělo sloužit jen $\mathrm{k}$ orientaci při diskusi o podkladu. Tato funkce se bohužel nenaplnila, nebot’ předpojatý záměr se prosazoval mocensky a konkrétní argumenty se na zasedání AS MU nevyvracely pomocí protiargumentů, ale „přebíjely“ se podle mého soudu povýtce politicky: pouhým paušálním a nezlomným „pevným přesvědčením“ o opaku. 


\section{Motivace a východiska}

1. Předesilám, že jsem po řadu desetiletí byl a stále jsem př́ivržencem a propagátorem internacionalizace a prosazoval jsem ji po desetiletí jakožto akademický funkcionár i jako prostý učitel MU. Nepochybuji o strategickém významu internacionalizace, ale kritizuji z oborového hlediska jen jeden nedostatečně promyšlený a odůvodněný záměr, který může být $\mathrm{v}$ oboru práva kontraproduktivní a může vyvolat řadu vedlejších nepř́iznivých důsledků.

2. Hovořím ovšem nejen za sebe, a nejen jako formálně zvolený senátor, ale i jako neformální mluvčí řady nejkvalifikovanějších a nejzkušenějších členů akademické obce naší fakulty, kteří se $\mathrm{s}$ návrhem seznámili a $\mathrm{v}$ předložené podobě jej pokládajî za absurdní a nepřijatelný. Činím tak i přes svoje tušení hraničící s jistotou (a nebo právě proto), že o návrhu je politicky rozhodnuto a že vedení MU je rozhodnuto prosadit jej za každou cenu.

3. Podávám vědomě především oborově limitovaný pohled. Některé poznámky a argumenty mohou však $\mathrm{v}$ obměně platit i pro jiné obory, a pro jiné zase určitě vůbec ne - naopak pro ně není třeba nic pririrozenějšího než to, co se navrhuje. Ale problém je právě v onom paušálním a direktivním řešení, jež je sice možná administrativně pohodlné a mediálně působivé, ale jež je necitlivé a v oboru práva prímo kontraproduktivní.

4. Z hlediska právních oborů upřednostňuje komentovaný návrh formu před obsahem a kvalitou. Myslím, že (v rozporu s dobře míněným cílem) naopak kvalitu habilitačních prací a habilitačního řízení u naprosté většiny habilitačních právních oborů ohrozí nebo sníží a že zhorší postavení a sníží potenciál kvalifikačního růstu naší právnické fakulty $\mathrm{v}$ národním měrítku.

5. Nemyslím si a vůbec netvrdím, že podpora cizojazyčné komunikace na MU je špatná. Podpora a motivace odpovídající různorodosti a zvláštnostem akademického prostředí však není totéž, co silové prosazování jednotného řešení „na povel“.

6. Kvalita habilitačních prací a personální a obsahová úroveň celého rúzení jsou ze zákona zásadně $\mathrm{v}$ gesci fakultních vědeckých rad. Univerzita zajišt’uje především formální jednotnost rízení a VR MU se jen ve zcela výjimečných případech na návrh rektora vyjadřuje $\mathrm{k}$ návrhu fakulty na jmenování docentem. ${ }^{4}$ Vědecké rady fakult by proto neměly být postaveny v tak zásadní otázce, jako je jazyk základního dokumentu habilitačního ř́zení, prèed „hotovou věc“.

7. Jazykový cenzus kladený na habilitační práce nepokládám za pouhý formální požadavek týkající se postupu $\mathrm{v}$ rízení (byt' bez jeho splnění nemá být zásadně dalšì postup uchazeče možný vůbec). Jazyk totiž přinejmenším v právu (ale i v řadě filologických oborů a jinde ${ }^{5}$ ) výrazně ovlivňuje a podmiňuje obsahovou stránku práce, jak se dokumentuje níže.

4 Srov. \ 72 odst. 11 zákona o vysokých školách.

5 Představuji si třeba i absurditu či přinejmenším násilnost anglicky psané habilitace $\mathrm{v}$ - jinak $\mathrm{k}$ tomu vhodném - oboru informatiky s tématem zvláštností češtiny při algoritmizaci překladů či ve vyhledávačích. 


\section{Některá věcná hlediska}

8. Předmětem právnických habilitačních prací jsou velmi často úzká témata vázaná na národní právní úpravu. Jazykové nařízení bude nepřímo uměle a násilně omezovat volbu témat tak, aby se národním právem pokud možno nezabývaly. To může představovat diskriminační zásah do obsahové stránky řízení.

9. Okruh specialistů splňujících faktické i formální kvalifikační znaky požadované pro členství v habilitačních komisích a pro zpracování oponentských posudků je v některých oborech dosti omezený; často bývá problém sehnat vůbec kvalitního oponenta. „Obrat k cizině“ není východiskem - vzhledem ke specifice tématu se takový oponent totiž často v zahraničí vůbec neexistuje.

10. S výjimkami nejsou zásadně dostupní cizojazyční oponenti, kteří budou dostatečně rozumět českému právu včetně judikatury, odborné literatury a komentářů, které jsou a vždycky budou publikovány výhradně v češtině.

11. I kdyby se podařilo sehnat zahraničního odborníka na zpracované téma, málokdo z nich se odváží poctivě prohlásit, že kromě svého národního právního řádu se dostatečně a nezprostředkovaně orientuje v českém právním prostředí. Může nastat paradoxní důsledek takové nejistoty oponentů: posouzení povrchní a pro forma, snižující standard obsahové náročnosti.

12. Předpoklad, že cizojazyčná habilitační práce o českém právu najde nejméně stejně tak kvalifikované posuzovatele v zahraničí, je tedy lichý. Málokterý odpovědný zahraniční právní odborník si troufne tvrdit, že zná naše právo aspoň tak dobře, jako český habilitant. Má sice k dispozici v cizí řeči habilitační práci, ale nikoliv všechny potřebné související právní předpisy, judikaturu, komentáře, a vưbec národní odborný právnický diskurs; není schopen sledovat aktuální vývoj a rozpornost judikatury, nálezů Ústavního soudu, posoudit problémy v kontextu našeho právního řádu.

13. Bude-li oslovený kandidát odpovědný, odmítne funkci oponenta. Soudím tak podle sebe a svých kolegů, kteři sice v cizích jazycích čteme, píšeme, konferujeme, přednášíme našim i zahraničním studentům, vedeme občas i cizojazyčné diplomové práce a oponujeme doktorské práce cizinců, ale analogickou nabídku na oponování práce o cizím právu bychom odmítli.

14. Najde-li se méně svědomitý a spřátelený oponent, který si na posudek „troufne“, budeme mít tedy posudek ,z ciziny“; můžeme ale setrvat v romantickém sebeklamu, že proto bude i bude kvalitnější než od skutečného českého znalce?

15. Závěr je, že jazykový cenzus nám okruh a kvalitu tuzemských oponentů nemůže zvýšit, ale jen snížit; žádnou (natož pak lepšî) náhradu ze zahraničí přitom nezískáme. To je ovšem v prrímém protikladu k tomu, čeho se chce komentovaným opatřením dosáhnout.

16. I z těch potenciálních tuzemských oponentů budou jazykovým cenzem vyřazeni třeba i ti oborově nejlepší, protože naneštěstí neznají jazyk, v němž byla práce sepsána. 
17. Navrhovaný jazykový cenzus pravděpodobně sníží počet možných nejlepších oponentů, kteří jsou odborně $\mathrm{v}$ daném tématu vůdčími a referenčními osobnostmi, ale neovládají dostatečně nebo vůbec jazyk zvolený k sepsání habilitační práce. Nemusí se také najít v tuzemsku žádný takový.

18. Habilitační práce je většinou výsledkem předchozích studií a výstupů, které by patrně měly také být $\mathrm{v}$ př́slušném cizím jazyce, což by ale $\mathrm{v}$ právu bylo často samoúčelné. $\mathrm{V}$ některých oborech (a v právu většinou) nenabude angličtina ani jiný cizí jazyk postavení lingua franca.

19. Výše uvedené výhrady se týkají v právu i složení habilitační komise - pokud by se měli její členové vybírat podle toho, aby hlavně rozuměli jazyku, v němž je práce sepsána.

20. Habilitační právnické práce bývají velmi rozsáhlé ${ }^{6}$ a běžně se vydávají knižně předem. Představují často významný přínos nejen pro právní teorii a pro interpretaci, ale i pro rozhodovací praxi; o cizojazyčnou verzi však nebude zájem ani nakladatelský, ani čtenářský. ${ }^{7}$ To povede k samoúčelnosti jinojazyčné habilitační práce a bude se ztěžovat praktický dopad habilitačních prací. Jazykové nařízení vytvoří umělou hradbu proti společenskému dopadu habilitantova díla překonatelnou jen za cenu velmi nákladného překladu ${ }^{8}$ do češtiny nebo za cenu paralelní existence dvou jazykových verzí. Takže uchazeč asi napíše práci česky a nechá si ji na vlastní náklady přeložit. Fakulta i MU na takto vzniknuvších nákladech participovat patrně nehodlají. Tak se v našich oborech vyvolají diskriminační až prohibitivní náklady.

21. Vytvořit českou paralelní verzi habilitační práce není řešení, ale spíše vynucený úskok, který může vyvolat další problémy.

22. Jinou komplikaci předvídám při existenci dvou jazykových mutací v tom, o které z nich se povede řízení a na kterou se budou psát posudky. Odhaduji, že zvítězí verze česká. Ona cizojazyčná verze zůstane jen pro forma dokladem o „úspěšné internacionalizaci“. Co se stane, nebude-li překlad přesný nebo nebudou-li verze obsahově identické? Tyto důsledky asi nejsou cílem internacionalizace.

23. Odhaduji rizika diskriminace

a) oborové (diskriminují se právní obory, v nichž na rozdíl od „,tvrdých věd“ angličtina obecným komunikačním jazykem není; ${ }^{9}$ vznikne nebezpečí, že se kvalita bude podřizovat jazykovému cenzu),

b) osobní (habilitant na jiné tuzemské fakultě bude mít řízení snadnější a lacinějšî) i

c) mezifakultní (budeme odrazovat zájemce už samotným požadavkem a potom komplikacemi v řízení z něho plynoucími, budeme diskriminováni z hlediska habilitačních řízení mezi českými právnickými fakultami). Svoje vlastní kandidáty

6 Výjimkou nejsou ani několikasetstránkové práce (a to nikoliv v normostranách, ale v tiskových stranách).

7 Anglicky psaná práce o českém právu nebude zajímat české právníky, a možná jen výjimečně zaujme pár zahraničních právníků - ovšem v rozsahu, který nakladatelství určitě neosloví.

8 Šlo by o statisíce korun.

9 Podotýkám, že ji přitom nenahrazuje ani němčina, francouzština, či jiný světový jazyk. 
budeme tímto požadavkem nepřímo vytlačovat na jiná pracoviště. Akreditovanou způsobilost fakulty vést habilitační rízení a její stávající kapacitu tímto opatřením určitě neposílíme, ale naopak poškodíme.

24. Namítám mezinárodní raritnost navrhovaného řešení, přinejmenším pokud jde o právo.

25. Vadí mi kulturně negativní ponížení (odsunutî) národního jazyka jako neplnohodnotného komunikačního prostředku v oborech, které nemají jiné symbolické jazyky (jako je mají „tvrdé، vědy). Právní argumentace je vedena vesměs jen přirozeným jazykem a zbavovat habilitanta možnosti vyjádřit se dokonale a přiléhavě tím, že musí svoje zatím vrcholné dílo sepsat v cizím jazyce bez možnosti opory ve formálních jazycích, je oborově diskriminační. ${ }^{10}$

Právní věda se utváří v odborném druhu přirozeného jazyka a její rozvoj nelze oddělit od rozvoje jazyka, v němž existuje.

26. V právu se angličtina (ani žádný jiný jazyk) nestane kvůli navrhované obligatornosti habilitací obecným komunikačním prostředkem. V̌̌dy jím z povahy věci bude čeština. Cizí jazyky se většinou používají a budou používat jen v prípadě prosté informace o našem právu včetně př́padné komparace, nebo v úzkých a nečetných specializacích bez vztahu k platnému národnímu právu. O českém právu se však vždy psalo a bude psát především česky, o německém německy, o francouzském francouzsky, atp. Nevidím důvod, proč z toho má být nařízena výjimka právě u tak významných právních pojednání, jako jsou habilitační práce. Vědecké práce o právu je nutné psát v češtině. Práce habilitační je přitom klíčovým krokem „zrodu“ univerzitního vědce. Jiný přístup bude dlouhodobě poškozovat nejen českou právní vědu, ale i tvorbu české právní terminologie a podobu českého práva. ${ }^{11}$

27. Myšlenka cizojazyčné habilitace není špatná sama o sobě a v řadě oborů je odborná komunikace v cizím jazyce dávno běžná a krokem zpět by byl návrat $\mathrm{k}$ češtině. V právu to však zásadně neplatí. I zde jsou výjimky a nejedna práce, dokonce diplomová, byla v cizím jazyce sepsána. Nikoliv však povinně, ale když to předmět zkoumání a jazykový úzus prríslušné odborné komunity umožňoval nebo přímo vyžadoval.

\section{Poznámky k formálním hlediskům}

28. Výjimka z eventuální povinné cizojazyčnosti práce by měla být transparentní, předvídatelná a normativní, nikoliv arbitrární a nepřezkoumatelná. Bianco zmocnění VR MU („, odůvodněných př́ípadech“) je naopak netransparentní a povede $\mathrm{k}$ nepřezkoumatelnosti jak při udělení, tak při neudělení výjimky. Výjimka by neměla záviset na posouzení VR MU ve výjimečných prrípadech ad hoc.

10 Bez podivení se dá sotva hodnotit snaha zakázat na národní univerzitě jakožto vrcholné kulturně vzdělávací instituci, aby se uchazeč ve svém díle představujícím dosavadní vrchol jeho odborného vývoje mohl vyjádřit ve vlastním rodném jazyce ve vlastní zemi.

11 Srov. již dnes používané některé mechanické legislativní překlady implementovaného evropského práva, jež aplikační praxe není s to smysluplně interpretovat. 
29. Habilitační řízení je spojeno s podáním práce. Není jasné, zda má uchazeč napřed napsat práci a pak žádat o výjimku ex post (což by bylo docela absurdní), nebo zda má požádat o výjimku předtím, než práci napíše a než vưbec může přesvědčivě doložit, že jde o tzv. „odůvodněný př́pad“.

30. Čl. 2 odst. 3 návrhu řádu prripouští jakýkoliv jiný jazyk „,podle zvyklostí v oboru“ žádné takové jazykové zvyklosti v našem právu ovšem nejsou. Ty totiž předpokládajî tradici a dlouhodobost. Nenahradí je nařízení povinné angličtiny. Jazykovou zvyklostí v právu je použití češtiny; anglicky se komunikuje jen v úzkých segmentech. Uchazeč se asi nemůže uchýlit do kteréhokoliv jazyka (kromě výslovně vyloučené slovenštiny). ${ }^{12}$ Je ovšem otázka, zda by habilitační komise mohla práci již sepsanou v cizím jazyce odmítnout jen proto, že tento jazyk neovládá dostatečný počet členů komise. U české práce je to nemyslitelné. A budeme vůbec moci odmítnout cizojazyčnou práci jen proto, že neodpovídá ,jazykovým zvyklostem“?

31. Jistý problém, jenž se překonat dá, spočívá v oblasti právní terminologie. Některé právní pojmy a instituty nemají v angličtině nebo v němčině či jiném jazyku presesnou obdobu. $V$ řadě př́padů oponenti vytýkají habilitantům pojmoslovné prohřešky a nepřesnosti, jichž se habilitanti dopustili dokonce v rodném jazyce. To nebudou moci vytknout u práce sepsané v cizím jazyce, který ani přesným nástrojem pro vyjádření našich institutů být nemůže. U habilitanta se tedy ev. nepřesnost v české terminologii nebude moci namítat prostě proto, že se ani nezjistí.

32. Vyřešen není vztah k jazyku, v němž se povede řízení. Podle čl. 4 odst. 4 Směrnice MU 1/2016 o habilitačním řízení mohou účastníci ř́zení jednat v jazyce českém, slovenském či anglickém. Myslím, že stejně či podobně by se měl upravit i jazyk práce. Podobně čl. 5 odst. 2, j), iv) Směrnice předpokládá, že práce může být v češtině, slovenštině nebo angličtině. Členové VR nejsou přece povinni ovládat jazyk, v němž je sepsána habilitace. Přitom oni to jsou, kdo tajným hlasováním rozhodují o návrhu na udělení docentské hodnosti a mají mít přístup $\mathrm{k}$ habilitační práci a mají mít možnost seznámit se s ní přímo, a ne jen $\mathrm{v}$ převyprávění z cizojazyčného originálu.

\section{Správní řád a zákon o vysokých školách}

33. Obecným úředním a komunikačním jazykem je čeština. ${ }^{13}$ Ale podle $\int 72$ odst. 13 zákona o vysokých školách se na habilitačni rízeni správní rád nevątabuje; podrobnosti postupu pri habilitačnim rízeni stanovi vysoká škola ve svém vnitrnim predpisu. Habilitační řízení nicméně správním řízením svého druhu je. Nemyslím si, že bychom mohli porušit i takový základní princip řízení, jímž je jeho vedení v češtině.

34. Nutíme české uchazeče podstoupit správní řízení s podklady v nikoliv rodném a úředním jazyce, což může být diskriminační. Jakým právem nutíme člověka

12 Třeba podle země, kde má hodně kamarádů, a kde sežene ochotné oponenty...

13 Podle správní řádu, části 2, hlavy II, S 16: Jednací jasyle (1) V rízení se jedná a pisemnosti se vyhotovuji v českém jazyce. Úćastnici ř́zeni mohou jednat a pisemnosti mohou být prédkládány i v jasyce slovenském. 
vyjadřovat se ve vlastní zemi nepřesně a nedostatečně, když by v rodném jazyce byl schopen mnohem přiléhavějšího a plastičtějšího vyjadřování? Navíc to může být chápáno jako diskriminační přístup $\mathrm{k}$ docentuře coby neprrímé cestě $\mathrm{k}$ pracovnímu poměru na dobu neurčitou.

35. Ustanovení \ 72 odst. 13 zákona o vysokých školách zmocňuje: podrobnosti postupu při habilitačním řízení stanoví vysoká škola ve svém vnitřním předpisu. Kvalitu habilitační práce určuje zákon: a) písemná práce, která přináší nové vědecké poznatky, nebo b) soubor uveřejněných vědeckých prací nebo inženýrských prací doplněný komentářem, nebo c) tiskem vydaná monografie, která přináší nové vědecké poznatky. V prŕpadě sub b) by se do „habilitačního souboru prací“ nesměly zahrnout práce napsané „pouze“ česky? To pokládám opět za diskriminační.

36. „Postupem“ při habilitačním řízení podle $\int 72$ odst. 13 ZVŠ se rozumí povýtce procesní otázky, nikoliv obsahové náležitosti habilitační práce, které stanoví $\int 72$ odst. 3 zákona a jejichž obsahové naplnění posuzují oponenti, habilitační komise a VR fakulty.

37. Pokud si ani Směrnice MU o habilitačním řízení nedovoluje stanovit rozsah habilitační práce (nebot' se nejedná o podrobnost postupu při habilitačním řízení), který se správně ponechává na odborném posouzení habilitačních orgánů fakulty, působí paradoxně, chce-li MU plošně nařídit cizojazyčnost práce. S fakultativností anglické habilitační práce a řízení v angličtině přitom počítá Směrnice již dnes.

38. Navrhované univerzitní ,jazykové nařízení “ je praeter legem a je sporné, zda nepřekračuje zmocnění dané zákonem - netýká se totiž podrobností postupu při řízení podle zmocnění ZVŠ, ale zavádí kontroverzní jazykový cenzus s diskriminačním potenciálem.

39. Nevyjasněná je otázka, kdo bude ručit za jazykovou úroveň práce? Některé obory si vystačí díky symbolickým umělým jazykům s podstatně jednodušší angličtinou nežli obory právní. Obávám se, že cenou za povinně cizojazyčné habilitační práce budou v právu bud' banalizace (trivializace) jazykové úrovně a/nebo excesivní náklady vynaložené na překlady či revizi rozsáhlých několikasetstránkových spisů. To je oborově diskriminační.

40. Jazykový cenzus bude tlačit uchazeče nejen k simplifikaci obsahu, ale i ke stlačování rozsahu práce na nezbytné minimum. To je další negativní vedlejší dopad.

41. Budeme schopni uhájit pozici, že odmítáme habilitační práci proto, že garant oboru neovládá dostatečně řeč, $\mathrm{v}$ níž byla práce sepsána, nebo že není s to zajistit dostatečně kvalifikované oponenty vyhovující jazykovému cenzu danému uchazečovou jazykovou volbou?

\section{Závěry a návrhy}

42. Zavedení jakékoli změny vyžaduje nejdříve diskutovat o sledovém cíli, posoudit alternativní či variantní nástroje k jeho dosažení, jakož i předpokládané pozitivní 
a negativní externality. Vyžaduje to odpovědně vážit a vybrat takové řešení, které má rozumný potenciál dosáhnout zamýšleného účelu a nezpůsobuje nezamýšlené negativní důsledky. Pokud takové analýzy a hodnocení návrhu cizojazyčných habilitací proběhly a já o nich pouze nevím, mohlo to samozřejmě mít vliv na moje stanovisko k věci.

43. Nesouhlasím s tím, aby se tak zásadní změna, jako je významná obligatornost habilitačních prací, prosazovala bez odpovídajícího projednání širší akademickou veřejností (nejen v AS MU), a navíc v tak petrifikované formě, jakou představuje vnitřní předpis, a nikoliv v podobě mnohem flexibilnější směrnice (pokládá-li tedy vedení MU za nezbytné tento požadavek na MU takto plošně prosazovat).

44. Výše poukazuji na některé

a) specifické negativní právně oborové souvislosti a důsledky takového opatření, kvưli nimž s ním nesouhlasím. Poukazuji též

b) na nezanedbatelná právní rizika, která jsou obecná, a jimž by se mohla MU vyhnout nebo je minimalizovat.

45. O tom, budeme-li (ev. naši nástupci za několik let) testovat oborové dopady a externality jazykového cenzu u habilitačních prací a právní rizika s tím spojená cestou pokusu a omylu, se rozhodne mocensky.

46. Rozhodneme-li se, že ano, představuje menší riziko úprava formou flexibilnější směrnice, a nikoliv vnitřního předpisu MU. Skutečnost, že postup v habilitačním řízení má být upraven vnitřním předpisem, neznamená, že v něm musí být bezpodmínečně zahrnuto sporné komentované ustanovení o cizojazyčnosti habilitační práce; to lze stejně tak dobře umístit do Směrnice. Žádné nebezpečí z prodlení tu podle mého názoru nehrozí.

47. Aniž tvrdím, že jde o záměr, vytvoří se úpravou ve vnitřním předpisu bariéra nesnadné pozdější změny vnitřního předpisu (v podobě požadavků na její samotné schvalování a v požadavku jeho registrace MŠMT).

48. Pokud bychom se rozhodli nepřihlédnout ${ }^{14} \mathrm{k}$ námitce, že k jazykovému cenzu habilitací nemá vysoká škola zákonné zmocnění, protože nejde o úpravu postupu v řízenî (srov. zejm. body 35-38 tohoto podkladu) a chtěli bychom otázku jazyka upravit, je k tomu vhodnější forma Směrnice MU, nebot’ by - na rozdíl od předloženého návrhu čl. 2 odst. 3 Rádu habilitačního řízení - umožnila koncipovat př́padné jazykové požadavky
a) ex ante,
b) transparentně a
c) předvídatelně.

14 Pokud by se tedy vedení MU domnívalo, že jazyk habilitační práce je určením postupu v řízení, jen k němuž je zmocněno zákonem... 
49. Formulace jazykového požadavku by díky tomu mohla být diferencovaná a promyšlená s ohledem na specifičnost jednotlivých habilitačních oborů na univerzitě.

50. Za optimální a právně nejméně riskantní nicméně pokládám cizojazyčnost habilitační práce pouze doporučovat a pozitivně k ní uchazeče a fakulty motivovat, ale nezasahovat direktivně do habilitačních kompetencí fakultních vědeckých rad.

51. Př́padná úprava ve směrnici by nepřesouvala řešení na arbitrární a sotva přezkoumatelné rozhodování VR MU o výjimce z obligatorní cizojazyčnosti habilitační práce „V odůvodněných př́padech“.

52. Spoléhat se jako právník na takto koncipovanou iluzi arbitrární výjimky pokládám za bláhové.

53. Psychologicky útěšný odsun účinnosti jazykového cenzu o tři a pưl roku na obsahové podstatě věci nic nemění.

54. Myslím, že z hlediska formálního je to přesně naopak - právě to, že rozhodujeme o poměrech na univerzitě a pro dobu, v níž už třeba v rozhodujících funkcích ani působit nebudeme a nebudeme se možná ani muset nikomu zpovídat z důsledků našeho dnešního rozhodnutí, nás zavazuje ke zvýšené odpovědnosti a maximální uvážlivosti.

55. Než aby jazykový cenzus byl přijat ve sporné a netransparentní navrhované podobě, necht' je (má-li být vůbec v plošné podobě přijat) opravdu jasný a transparentní třeba o čtvrt či půl roku později.

56. Navrhuji tedy vypustit text čl. 2 odstavce 3 Návrhu Řádu habilitačního řízení a řízení

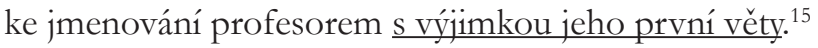

\section{Namísto závěru (post festum)}

Tento výše uvedený pozměňovací návrh si pan rektor jakožto předkladatel neosvojil. Návrh Řádu byl těsnou většinou hlasů členů AS MU dne 24. 4. 2017 schválen (bylo k tomu zapotřebí 26 hlasů; , „pro“ hlasovalo 27 senátorů a senátorek). Předpis již zaregistrovalo Ministerstvo školství, mládeže a tělovýchovy ${ }^{16}$ a stal se tedy součástí normativního prostředí MU. Doznal ovšem oproti původně předloženému návrhu určité změny, ${ }^{17}$ která se v rozporu se skutečností vydává za rozšíření možnosti výjimky ze zásady. ${ }^{18}$

15 Text č. 2 odst. 3 by tedy zněl: „Součástí návrhu na zahájení habilitačního řízení je habilitační práce uchazeče předkládaná v souladu s požadavky zákona.“

16 Dne 22. května 2017 pod č. j. MSMT - 12642/2017.

17 Poslední věta čl. 2, odst. 3 Ř́du (srov. znění podle pozn. pod čarou č. 1) ve schválené podobě zní: Vědec-

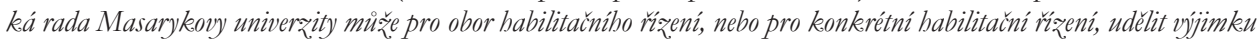
z. tohoto pravidla, a to na návrh predložený se soublasem vědecké rady fakulty.

18 Srov. odpověd' p. prorektora Bareše v anketě muni.cz - srov. https://www.online.muni.cz/udalosti/9343-anketa-habilitace-povinne-v-cizim-jazyce, 8. června 2017. 
Zatímco původní znění připouštělo udělení výjimky z cizojazyčnosti habilitační práce v „odůvodněných prípadech“, a to (implicitně) jak výjimky oborové (blokové), tak i individuální, podle schváleného a platného znění se „odůvodněnost př́padu“ nahrazuje procedurálním požadavkem, že návrh na výjimku může předložit jen děkan fakulty a navíc s předchozím souhlasem vědecké rady fakulty. To ve srovnání s původním zněním návrhu možnosti výjimek jednoznačně zužuje a formalizuje.

Výše mj. dovozuji, že nařízení cizího jazyka habilitační práce je exces a v řadě oborů nepřímo předurčuje obsah práce. Násilně mj. omezí volbu témat zabývajících se národním právem. ${ }^{19}$

Zákaz používat na národní univerzitě rodný jazyk ve vrcholné práci kandidáta je diskriminační. Hrozí banalizace jazyka, primitivizace odborného stylu a redukce rozsahu na nezbytné minimum. Hrozí, že bude odrazovat od tvorby rozsáhlých zásadních děl a že bude motivovat spíše k tvorbě účelových pokud možno minimalistických textů v jednoduché a/nebo špatné angličtině pro oponenty.

Hrozí navíc nebezpečí dvojkolejnosti: ř́izení o české metaverzi cizojazyčné práce. Vytvoři se umělá překážka společenského vlivu právnických habilitací kvưli pohodlí zahraničního oponenta. Okruh kompetentních oponentů se nerozšíríi, ale zúží.

Nepokládám za št’astné zbytečné rozštěpení senátu i univerzitní veřejnosti kvưli násilnému přitesávání všech do ,jedné velikosti.“ Nepochybuji o motivaci předkladatelů návrhu Ř́du dobrými úmysly; necht’ se, prosím, proto nepochybuje i o stejné motivaci oponentů plošné a mechanistické „cizojazyčné habilitační povinnosti“.

Těsné hlasování Akademického senátu vybavilo ,jazykové nařízení“ jen chabou legitimitou a mělo by nabádat spíše ke zdrženlivosti při jeho prosazování, resp. k velkorysosti při udělování výjimek.

Zdá se ovšem, že casus belli schválením Řádu nekončí. Nově připravovaná univerzitní Směrnice o habilitačním ř́zení o řízení ke jmenování profesorem, která by z povahy věci měla být čistě procedurální a technicistní, nevylučuje další obsahová kontroverzní „překvapení“.

19 Když jsem na okraj jednání AS MU v diskusi s vysokým představitelem univerzity argumentoval, že naše habilitační práce mají třeba i pět set tištěných knižních stran a že nařizovat jejich sepsání v cizím jazyce nebo překlad do něj je diskriminační, ne-li přímo prohibitivní, opáčil mi, že takové rozsáhlé spisy si jako habilitační práce nepředstavuje. To je ovšem při vši úctě otázka měřítek nastavovaných fakultními vědeckými radami a oborovými habilitačními komisemi, a nikoliv unifikovaných abstraktních představ vedení univerzity. 